\title{
Distribution and Abundance of Pre-recruit and Commerical-sized American Plaice on the Grand Bank
}

\author{
S. J. Walsh \\ Department of Fisheries and Oceans, Fisheries Research Branch, \\ Northwest Atlantic Fisheries Centre, P. O. Box 5667, \\ St. John's, Newfoundland, Canada A1C 5X1
}

\begin{abstract}
Length compositions of American plaice, Hippoglossoides platessoides (Fabr.), catches on the Grand Bank from spring stratified-random groundfish surveys during 1971-80 were analyzed to assess the distribution and relative abundance of pre-recruits and commercial-sized fish. Highest concentrations of both groups occurred on the north and northeast slopes of the bank which are strongly influenced by the cold Labrador Current. Both pre-recruit and commercial-sized American plaice were found in the same general areas at very similar depths and near-bottom temperatures, indicating that the nursery grounds for juveniles are not isolated from commercial fishing grounds.
\end{abstract}

\section{Introduction}

The greatest abundance of American plaice in the Northwest Atlantic occurs on the Grand Bank off Newfoundland (NAFO Divisions $3 \mathrm{~L}, 3 \mathrm{~N}$ and 30 ). The fishery, which has consistently yielded approximately 50,000 tons annually in recent years, occurs mainly on the northwestern part of the bank (Div. 3L) in depths of 70-185 m, along the southeastern edge of the bank (Div. $3 \mathrm{~N}$ ) in depths of 70-275 m, and to a lesser extent on the southwestern part of the bank (Div. 30) in depths of 70-185 m (Fig. 1).

Pitt (1967) concluded that large numbers of juvenile American plaice (ages 3-5 years) live principally on the shallow parts of the Grand Bank and postulated that these areas serve as nursery grounds for the young which are ultimately recruited to the exploitable population located on the slopes of the bank. The purpose of this paper is to investigate Pitt's (1967) hypothesis, to describe in some detail the relative distribution and abundance of "pre-recruit" American plaice less than the minimum commercial size of $30 \mathrm{~cm}$ (total length), and to compare the results with the corresponding distribution and abundance of commercial-sized fish $(\geqslant 30 \mathrm{~cm})$.

The American plaice population on the Grand Bank lives mainly under the influence of the cold Labrador Current (Pitt, 1975), which divides when it comes in contact with the shallow northern projection of the bank (about $47^{\circ} 35^{\prime} \mathrm{N}$ ). One branch of the current passes southwestward through the Avalon Channel with some southward flow over the shallow plateau of the bank, and the seaward branch continues southward along the eastern slope of the bank (Smith et al., 1937; Templeman, 1966). The warm Gulf Stream flows eastward south of the Grand Bank, and the mixing of cold and warm waters creates slope water of intermediate temperature which affects the southwest slope of the bank. Thus, temperature and depth are important parameters in any consideration of the distribution and abundance of both pre-recruit and commercial-sized American plaice on the Grand Bank.

\section{Materials and Methods}

The data used in this study were collected during groundfish surveys of the Grand Bank in the spring, with coverage of Div. $3 \mathrm{~L}$ and $3 \mathrm{~N}$ in 1971-80 and Div. 30 in 1973 and 1975-80. The surveys were conducted by the Canadian research vessel $A$. $T$. Cameron with a Yankee No. 41.5 otter trawl, the codend of which was lined with $30-\mathrm{mm}$ mesh netting. The trawl was towed at a speed of 3.5 knots $(108 \mathrm{~m} / \mathrm{min})$ for $30 \mathrm{~min}$ at each fishing station. The fishing locations were determined according to the stratified-random survey design for the Grand Bank (Doubleday, 1981; Pitt et al., 1981).

The American plaice catch at each fishing station was quantified by number and weight $(\mathrm{kg})$. Among the various biological data collected were length frequencies based on the measurement of fish as total length (TL) to the nearest centimeter. For analysis, the length frequencies of American plaice, weighted to the number caught at each fishing station, were divided into two major length groups, termed "pre-recruits" $(<30 \mathrm{~cm} \mathrm{TL})$ and "commercial-sized" fish ( $\geqslant 30 \mathrm{~cm} \mathrm{TL})$, and the first group was further subdivided into three size-groups (2-9 cm, $10-19 \mathrm{~cm}$ and $20-29 \mathrm{~cm})$. Distribution and relative abundance of each size-group are based on average catch-per-tow in each stratum after combination of data for 1971-80 (i.e. total number of fish caught per stratum divided by total number of tows per stratum). 


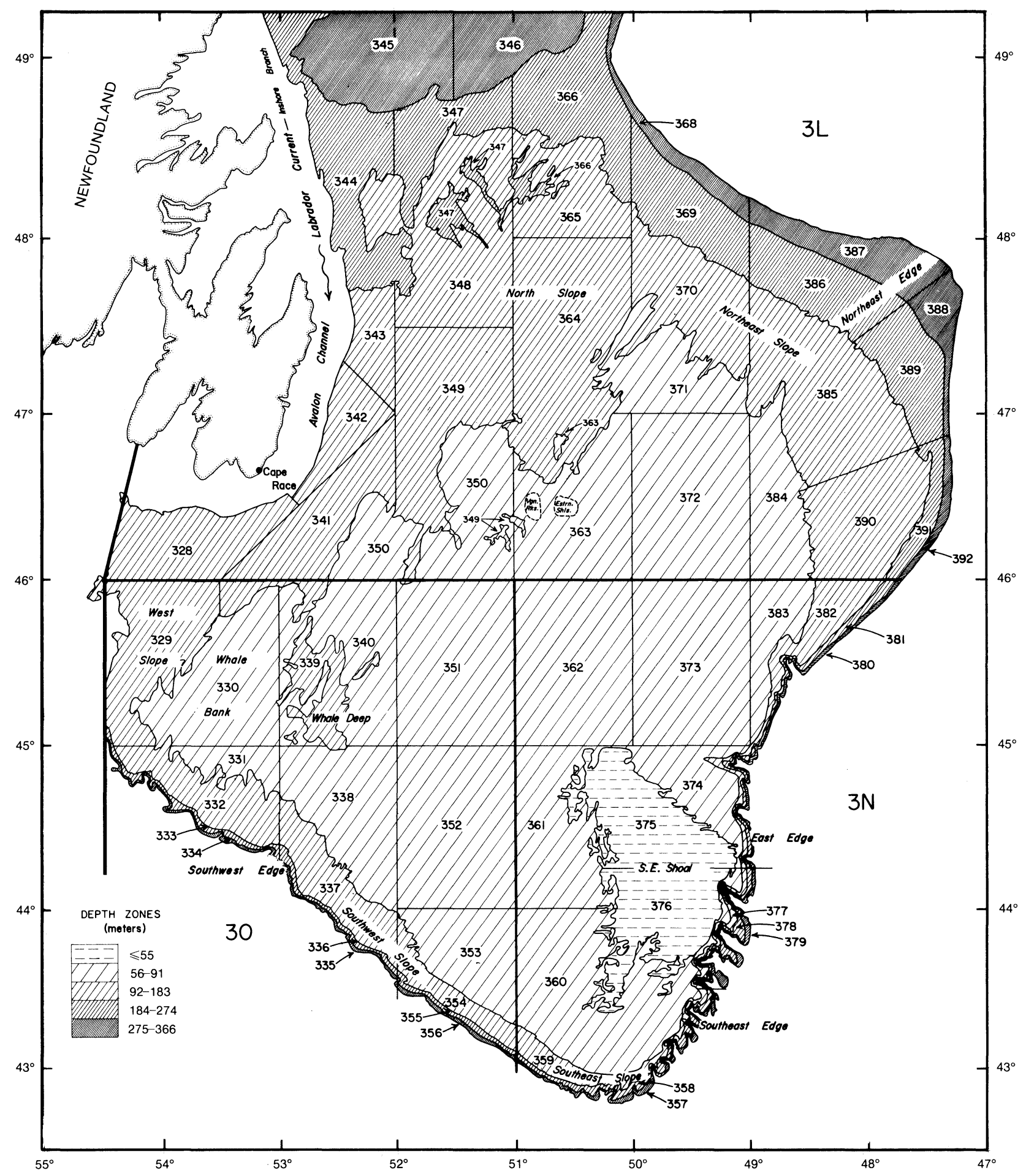

Fig. 1. Stratified-random survey design for the Grand Bank, with place names used in the text.

Bottom depth and near-bottom temperature data collected at each fishing station during the 1971-80 period were averaged for each stratum to examine the relationship between these parameters and the distribution and abundance of American plaice by stratum.
Mean depth and temperature preferences of the various size-groups of fish in each division were examined by calculating the overall average depth and temperature for each size-group using the numbers caught in each stratum during $1971-80$ as weighting factors. 

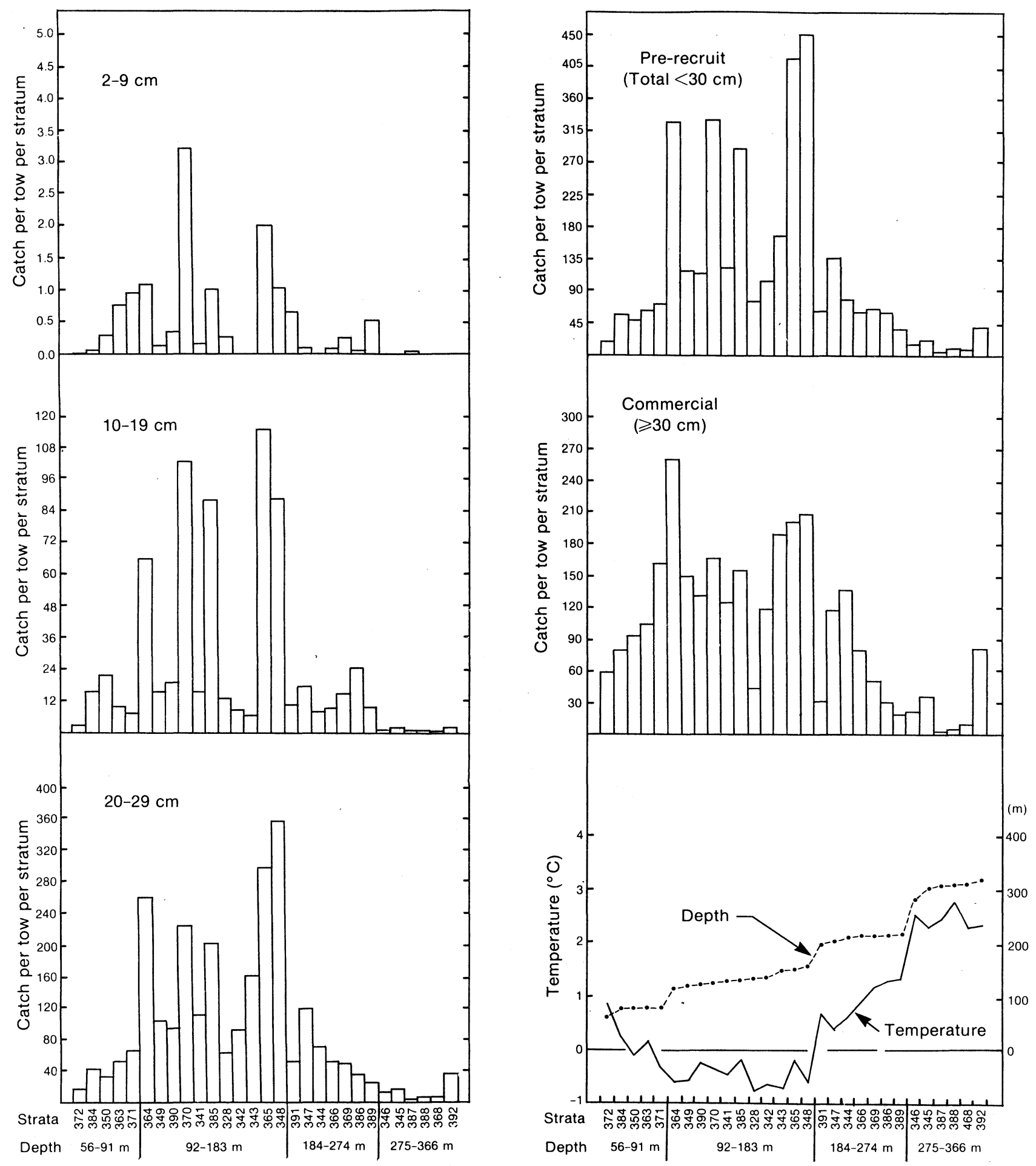

Fig. 2. Mean catch-per-tow by stratum for American plaice size-groups and associated mean depth and temperature trends in Div. 3L, 1971-80.

\section{Results}

\section{Distribution and relative abundance}

The average number of pre-recruit and commercial-sized American plaice caught per tow on the
Grand Bank (Div. 3L, 3N and 30 ) by stratum and depth interval are listed in Appendix Table A, together with the corresponding average depths and near-bottom temperatures. These data are illustrated separately by division in Fig. 2, 3 and 4. 

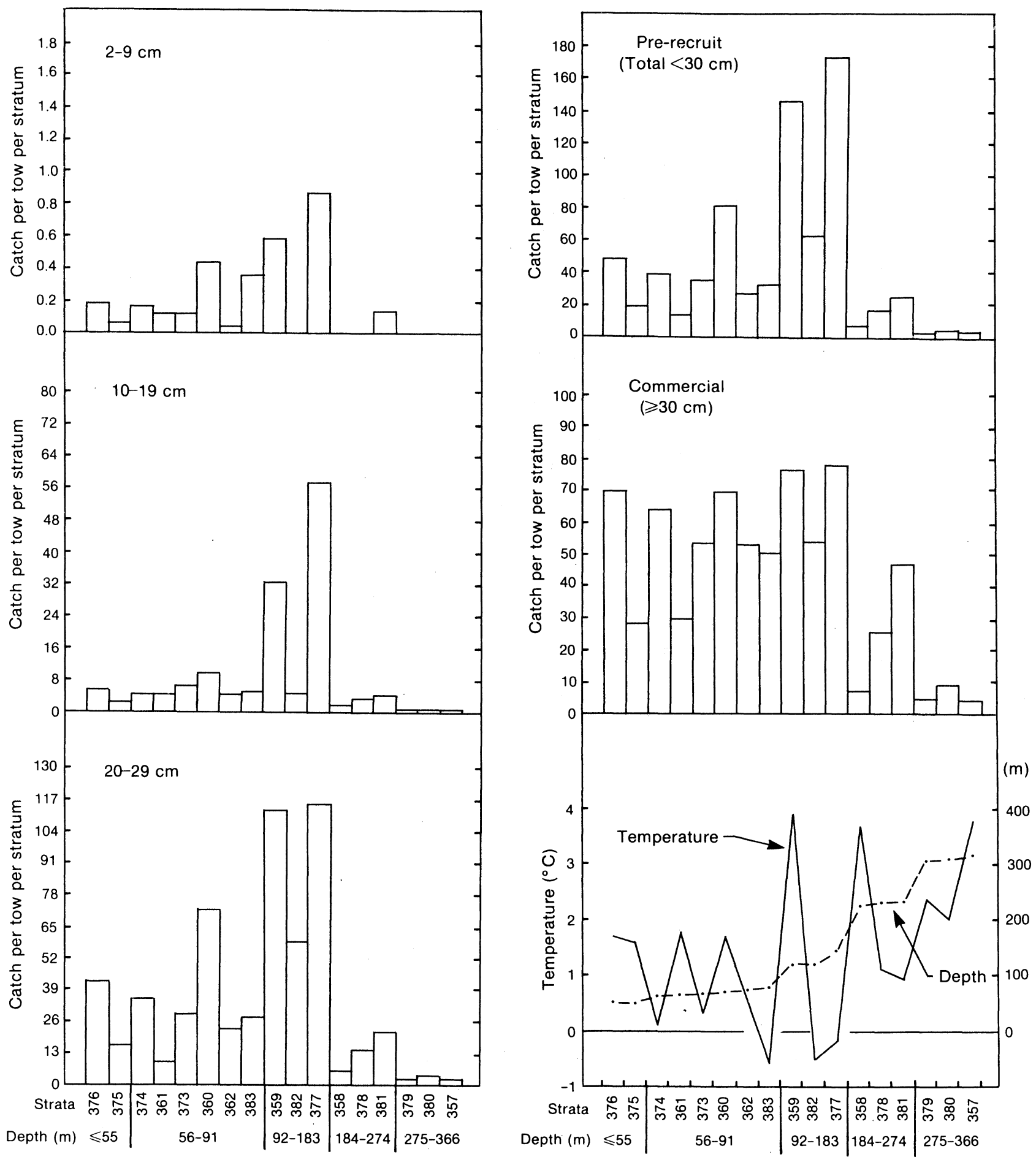

Fig. 3. Mean catch-per-tow by stratum for American plaice size-groups and associated mean depth and temperature trends in Div. 3N, 1971-80.

Division 3L. The highest concentrations of prerecruit and commercial-sized American plaice were distributed in various strata on the north and northeast slopes of the bank in depths of 92-183 m where temperatures were below $0^{\circ} \mathrm{C}$ (Fig. 2). Smaller quantities were found at shallower depths $(57-91 \mathrm{~m})$ where tempera- tures varied around $0^{\circ} \mathrm{C}$. In deeper strata on the slopes, the catch-per-tow of both size groups $(<30 \mathrm{~cm}$ and $\geqslant 30$ $\mathrm{cm}$ ) declined with increasing depth and temperature, except for the anomalously higher catches in stratum 392 (about $330 \mathrm{~m}$ ) where the average temperature was $2.4^{\circ} \mathrm{C}$. Very few small fish $(<20 \mathrm{~cm})$ were taken in the 

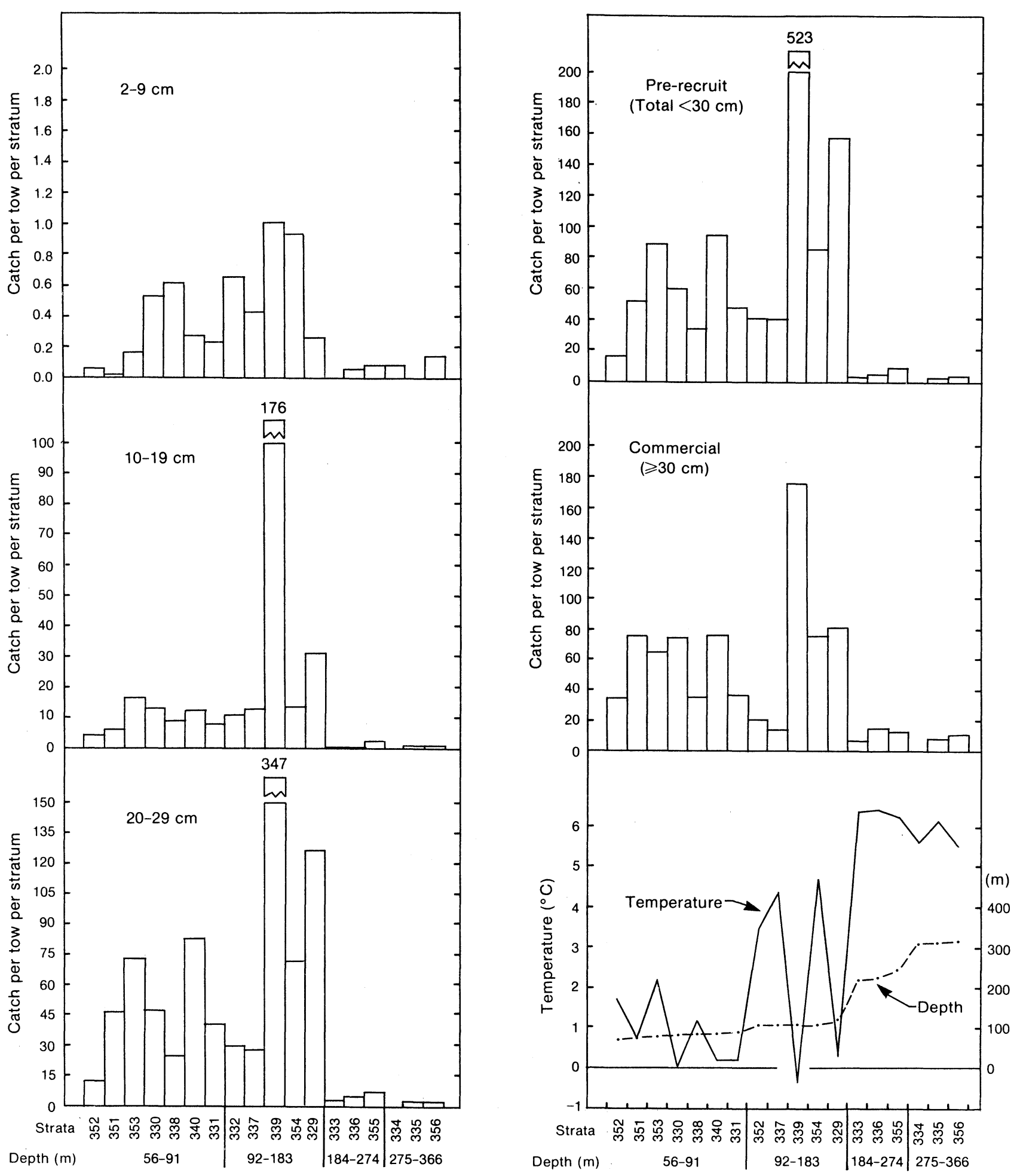

Fig. 4. Mean catch-per-tow by stratum for American plaice size-groups and associated mean depth and temperature trends in Div. 30, 1973-80.

deepwater strata $(\geqslant 275 \mathrm{~m})$. Among the three sizegroups of pre-recruits, there was great variation in catch-per-tow per stratum, particularly for the two smallest size-groups, but the distribution patterns show no obvious trends that could be construed as indicative of differences.
Division 3N. The highest concentrations of prerecruit American plaice of all three size-groups were found on the eastern slope in stratum 377 (143 m), where the mean temperature was slightly less than $0^{\circ} \mathrm{C}$, and on the southeast slope $(118 \mathrm{~m})$, where the temperature averaged $3.9^{\circ} \mathrm{C}$ (Fig. 3). Pre-recruits 
occurred in somewhat lesser abundance at shallower depths $(<92 \mathrm{~m})$, where the mean temperature generally ranged from $0^{\circ}$ to $1.8^{\circ} \mathrm{C}$, but commercial-sized fish were almost as abundant at most of these shallower strata as in the deeper strata $(92-183 \mathrm{~m})$. Along the eastern and southern slopes of the bank in depths greater than $183 \mathrm{~m}$, with characteristically warm bottom water below the cold core of the Labrador Current, concentrations of pre-recruit and commercial-sized American plaice were small, except in strata 378 and $381(230 \mathrm{~m})$ where the bottom temperature was about $1^{\circ} \mathrm{C}$ in each case. The trends in distribution of the three size-groups of pre-recruits by stratum were generally similar.

Division 30. The highest concentrations of both pre-recruit and commercial-sized American plaice were found in stratum 339 (Whale Deep, mean depth $107 \mathrm{~m}$ ) and in stratum 329 (West Slope, mean depth 115 $\mathrm{m})$ where the average temperatures were $-0.3^{\circ}$ and $0.3^{\circ} \mathrm{C}$ respectively (Fig. 4). Catches were moderate in shallower strata adjacent to Whale Deep (i.e. strata 351,330 and 340 ), where the mean temperatures ranged from $0.1^{\circ}$ to $0.8^{\circ} \mathrm{C}$, and surprisingly also in stratum $354(107 \mathrm{~m})$ on the southwest slope where the temperature averaged $4.8^{\circ} \mathrm{C}$. The deepwater strata along the southwest slope $(\geqslant 184 \mathrm{~m})$, where temperatures were higher than $5^{\circ} \mathrm{C}$, yielded very small catches of both pre-recruit and commercial-sized American plaice. No obvious difference in distribution was evident among the three size-groups of young fish.

\section{Depth and temperature preferences}

In each of the three major divisions of Grand Bank, pre-recruits tended to prefer slightly greater depths, on the average, than commercial-sized American plaice (Table 1), but the differences are not considered significant in view of the apparently large variances associated with the weighted mean depths. However, on the northern half of the bank (Div. 3L), both pre-recruit and commercial-sized fish tended to prefer considerably greater depths than those inhabiting the southern half of the bank (Div. $3 \mathrm{~N}$ and $3 \mathrm{O}$ ).

Temperature preferences of all size-groups of American plaice were, on the average, slightly below $0^{\circ} \mathrm{C}$ in Div. $3 \mathrm{~L}$, with little variation among the weighted mean values. They were somewhat higher around $1^{\circ} \mathrm{C}$, on the average, in Div. $3 \mathrm{~N}$ and 30 , with considerably greater variation among the weighted mean values. The greater temperature variation and the shallower preferred depths on the southern half of the Grand Bank implies that American plaice tend to avoid the deeper areas along the slopes which are more influenced by warm slope water than on the northern part of the bank which is directly influenced by cold water of the Labrador Current.
TABLE 1. Mean depth and temperature patterns for different sizegroups of American plaice on the Grand Bank, weighed by the catches of the size-groups in the various strata, 1971-80.

\begin{tabular}{|c|c|c|c|c|c|}
\hline \multirow[b]{2}{*}{ Div. } & \multirow{2}{*}{$\begin{array}{l}\text { Length } \\
\text { group } \\
(\mathrm{cm})\end{array}$} & \multicolumn{2}{|c|}{ Depth (m) } & \multicolumn{2}{|c|}{ Temperature $\left({ }^{\circ} \mathrm{C}\right)$} \\
\hline & & Mean & SD & Mean & SD \\
\hline \multirow[t]{5}{*}{$3 L$} & $2-9$ & 133.1 & 39.8 & -0.06 & 0.89 \\
\hline & $10-19$ & 141.6 & 36.9 & -0.09 & 0.76 \\
\hline & $20-29$ & 147.2 & 43.7 & -0.15 & 0.82 \\
\hline & $<30$ & 145.9 & 42.4 & -0.14 & 0.81 \\
\hline & $\geqslant 30$ & 139.7 & 54.4 & -0.04 & 0.93 \\
\hline \multirow[t]{5}{*}{$3 N$} & $2-9$ & 99.2 & 45.2 & 1.81 & 2.69 \\
\hline & $10-19$ & 113.8 & 49.6 & 1.11 & 2.03 \\
\hline & $20-29$ & 100.4 & 50.1 & 1.28 & 2.18 \\
\hline & $<30$ & 102.9 & 50.3 & 1.25 & 2.16 \\
\hline & $\geqslant 30$ & 94.2 & 55.8 & 0.91 & 1.68 \\
\hline \multirow[t]{5}{*}{30} & $2-9$ & 100.1 & 38.2 & 2.25 & 3.61 \\
\hline & $10-19$ & 103.0 & 24.8 & 0.77 & 2.17 \\
\hline & $20-29$ & 97.5 & 25.5 & 0.88 & 2.13 \\
\hline & $<30$ & 98.7 & 25.5 & 0.87 & 2.15 \\
\hline & $\geqslant 30$ & 93.3 & 33.5 & 1.07 & 2.04 \\
\hline
\end{tabular}

\section{Discussion and Conclusions}

The analysis of the survey data for $1971-80$ indicates that pre-recruit and commercial-sized American plaice occupy the same general areas of the Grand Bank. This does not support Pitt's (1967) hypothesis that the shallower parts of the bank serve as nursery grounds for the Grand Bank population, with the young fish (ages 3-5) moving deeper as they grow older. However, the areas of high abundance of American plaice are in agreement with Pitt's (1975) description of the sites of the commercial fishery.

The research vessel surveys were carried out only during the spring of each year, and, consequently, there are no data for comparison of concentrations of pre-recruit and commercial-sized American plaice during other seasons. Powles (1965) found mixtures of immature and mature American plaice along the southern slope of the Laurentian Channel (Gulf of St. Lawrence) at depths of 75-150 m (temperature range from -1.7 to $5.0^{\circ} \mathrm{C}$ ) during the spring, and both groups were found together at shallower depths $(40-100 \mathrm{~m})$ during the summer. McCracken (1963) reported that both immature and mature winter flounder, Pseudopleuronectes americanus, in the Bay of Fundy are found together in shallow water during the spring and also throughout a wider depth zone during the summer.

The distributional patterns evident from the overall weighted mean depths by size-groups for the three divisions (Table 1 ) indicate slightly greater mean 
depths for pre-recruit than for commercial-sized American plaice. Since the data base with respect to depth and temperature is a coarse one when considered over a 10-year period, it does not lend itself to tests of significance by standard statistical methods due to lack of homogeneity of variances. However, the magnitudes of the standard deviations in relation to the means indicate that the differences in mean depths are unlikely to be statistically significant. The smaller variation in the weighted mean temperatures on the northern part of the bank in contrast to the greater temperature variation found on the southern part of the bank indicates that American plaice have a relatively wide temperature tolerance, which Powles (1969) also found for the same species in the southern Gulf of St. Lawrence. The overall mean depths and temperatures for the various size-groups are within the ranges cited by Pitt (1967) and Powles (1969) in their studies of American plaice on the Grand Bank and in the southern Gulf of St. Lawrence respectively during the spring period.

The distribution of American plaice on the Grand Bank is closely linked to the early life history stages and the water circulation in the area. Spawning occurs during March-September over most of the Grand Bank, being most intense during April-May (Pitt, 1966; Nevinksy and Serebryakov, 1973). Unlike the same species (long rough dab) in the Barents Sea (Milinsky, 1944) and the European plaice, Pleuronectes platessa, in the North Sea (Bannister et al., 1974) which make fairly extensive spawning migrations, American plaice on the Grand Bank do not do so, according to the conclusion of Pitt (1969) from tagging experiments. After spawning, American plaice eggs and larvae are planktonic and drift with the currents until metamorphosis $(24-30 \mathrm{~mm}$ ) when the small juveniles descend to the bottom (Bigelow and Schroeder, 1953). Although the Labrador Current flows strongly southward along the western and eastern slopes of the Grand Bank, low current velocities and eddies over most of the shallow areas of the bank tend to retain the eggs and larvae over or near the spawning grounds (Nevinsky and Serebryakov, 1973). There is no evidence of larval drift to coastal nursery sites, as occurs for European plaice in the North Sea (Harding et al., 1978). Hence, the newly-metamorphosed juveniles ( $>20 \mathrm{~mm}$ ) tend to occupy the same areas of the bank as the adults which produced them several weeks earlier. Exceptions apparently occur in certain strata on the slopes around the bank where the occurrence of large juveniles and adults in the catches was not accompanied by the presence of 2-9 cm juveniles. Current velocities tend to be higher around the fringes of the bank, so that eggs and larvae may be transported by eddies away from the bank over oceanic depths or onto the shallow areas of the bank.
Relative to the catches of the large juveniles (10-29 $\mathrm{cm})$, the small catches of 2-9 cm juveniles undoubtedly do not reflect the abundance of this size-group. This may in part be attributed to inefficiency of the trawl in sampling over the entire range of this length-group, because the catches consisted mainly of 6-9 cm fish. The inadequacy of the Yankee No. 41.5 otter trawl for sampling very small flatfish has been reported for yellowtail flounder, Limanda ferruginea, by Pitt (1970), who found no 1-year-old and 2-year-old fish $(<12 \mathrm{~cm})$ in surveys of the Grand Bank. However, the relatively high catches of $10-19 \mathrm{~cm}$ and $20-29 \mathrm{~cm}$ juveniles and the similarity of their distributions by strata to those for adult American plaice in all three major divisions of the Grand Bank support the view that the nursery grounds for juveniles are not isolated from the commercial fishing grounds. A similar conclusion was expressed by Powles (1969) for the American plaice population in the southern Gulf of St. Lawrence. The concentration of juveniles in the same areas as commercial-sized fish was also clearly evident from the study of Stevenson (MS 1980), who estimated that the Canadian fishing fleet discarded 17 million and 29 million undersized American plaice on the Grand Bank in 1978 and 1979 respectively.

\section{Acknowledgements}

I am grateful to the many scientists and field technicians of the St. John's Biological Station (now named the Northwest Atlantic Fisheries Centre) who participated in the surveys and assisted in collecting the data, especially T. K. Pitt. Special thanks go to D. Stanbury for assistance in statistical analysis, to $\mathrm{C}$. Rose and $\mathrm{H}$. Mullett for preparing the illustrations, to $\mathrm{K}$. Mercer for the tabulations, and to D. Wells and J. Moores for their reviews of earlier drafts of the paper.

\section{References}

BANNISTER, R. C. A., D. HARDING, and S. J. LOCKWOOD. 1974 Larval mortality and subsequent year-class strength in the plaice (Pleuronectes platessa L.). In The early life history of fish, J. H.S. Blaxter (ed.), Springer-Verlag, Berlin, p. 21-37.

BIGELOW, H. B., and W. C. SCHROEDER. 1953. Fishes of the Gulf of Maine. Fish. Bull., U. S., 53, 577 p.

DOUBLEDAY, W. G. (Ed.). 1981. Manual on groundfish surveys in the Northwest Atlantic. NAFO Sci. Coun. Studies, 2: 1-55.

HARDING, D., J. H. NICHOLS, and D. S. TUNGATE. 1978. The spawning of plaice (Pleuronectes platessa) in the southern North Sea and English Channel. ICES Rapp. Proc.-Verb., 172: 102-113.

MCCRACKEN, F. D. 1963. Seasonal movements of the winter flounder, Pseudopleuronectes americanus (Walbaum), on the Atlantic coast. J. Fish. Res. Bd. Canada, 20: 551-585.

MILINSKY, G. I. 1944. On the biology and fisheries of the long rough dab in the Barents Sea. Trudy PINRO, 8: 388-415. (TransI. Ser. Fish. Res. Bd. Canada, No. 1298.)

NEVINSKY, M. M., and V. P. SEREBRYAKOV. 1973. American plaice, 
Hippoglossoides platessoides (Fabr.), spawning in the Northwest Atlantic area. ICNAF Res. Bull., 10: 23-36.

PITT, T. K. 1966. Sexual maturity and spawning of the American plaice, Hippoglossoides platessoides (Fabricius), from Newfoundland and Grand Bank areas. J. Fish. Res. Bd. Canada, 23: 651-672.

1967. Age and growth of American plaice (Hippoglossoides platessoides) in the Newfoundland area of the Northwest Atlantic. J. Fish. Res. Bd. Canada, 24: 1077-1099.

1969. Migrations of American plaice on the Grand Bank and in St. Mary's Bay, 1954, 1959 and 1961. J. Fish. Res. Bd. Canada, 26: 1301-1319.

1970. Distribution, abundance and spawning of yellowtail flounder, Limanda ferruginea, in the Newfoundland area of the Northwest Atlantic. J. Fish. Res. Bd. Canada, 27: 2261-2271.

1975. Changes in abundance and certain biological characteristics of Grand Bank American plaice, Hippoglossoides platessoides. J. Fish. Res. Bd. Canada, 32: 1383-1398.

PITT, T. K., R. WELLS, and W. D. McKONE. 1981. A critique of research vessel otter trawl surveys by the St. John's Research and Resource Services. Can. Spec. Publ. Fish. Aquat. Sci., 58: 42-61.

POWLES, P. M. 1965. Life history and ecology of American plaice (Hippoglossoides platessoides Fabr.) in the Magdalen Shallows. J. Fish. Res. Bd. Canada, 22: 565-598.

1969. Size changes, mortality, and equilibrium yields in an exploited stock of American plaice (Hippoglossoides platessoides). J. Fish. Res. Bd. Canada, 26: 1205-1235.

SMITH, E. H., F. M. SOULE, and O. MOSBY. 1937. The Marion and General Greene expeditions to Davis strait and Labrador Sea, 1928-1935. Scientific reports, Part 2. Bull. U. S. Coast Guard, 19, $206 \mathrm{p}$.

STEVENSON, S. C. MS 1980. Summary of discarding and estimates of the total removals by Canadian trawlers during the 1978 and 1979 Div. 3LNO American plaice fishery. NAFO SCRDOC., No. 86 , Serial No. N140.

TEMPLEMAN, W. 1966. Marine resources of Newfoundland: outline of hydrographic conditions. Bull. Fish. Res. Bd. Canada, 154: 23-27. 
APPENDIX

TABLE A. Average catch (numbers) per tow per stratum of American plaice by depth on the Grand Bank (Div. $3 \mathrm{~L}, 3 \mathrm{~N}$ and $3 \mathrm{O}$ ) from research vessel surveys, 1971-80

\begin{tabular}{|c|c|c|c|c|c|c|c|c|c|c|}
\hline \multirow{2}{*}{$\begin{array}{l}\text { NAFO } \\
\text { Div. }\end{array}$} & \multirow{2}{*}{$\begin{array}{l}\text { Depth } \\
\text { range } \\
(\mathrm{m})\end{array}$} & \multirow{2}{*}{$\begin{array}{l}\text { Stratum } \\
\text { number }\end{array}$} & \multirow{2}{*}{$\begin{array}{c}\text { No. } \\
\text { of } \\
\text { tows }\end{array}$} & \multicolumn{5}{|c|}{ Average number per tow by size group $(\mathrm{cm})$} & \multirow{2}{*}{$\begin{array}{c}\text { Average } \\
\text { depth } \\
(\mathrm{m})\end{array}$} & \multirow{2}{*}{$\begin{array}{c}\text { Average } \\
\text { temp. } \\
\left({ }^{\circ} \mathrm{C}\right)\end{array}$} \\
\hline & & & & $2-9$ & $10-19$ & $20-29$ & $<30$ & $\geqslant 30$ & & \\
\hline \multirow[t]{29}{*}{$3 \mathrm{~L}$} & $57-91$ & 372 & 47 & 0.02 & 2.60 & 16.66 & 19.28 & 58.81 & 69.3 & 0.89 \\
\hline & & 384 & 22 & 0.05 & 15.18 & 42.68 & 57.91 & 80.27 & 78.4 & 0.25 \\
\hline & & 350 & 48 & 0.29 & 21.52 & 30.92 & 52.73 & 93.31 & 80.4 & -0.07 \\
\hline & & 363 & 46 & 0.76 & 9.57 & 52.76 & 63.09 & 104.26 & 81.5 & 0.18 \\
\hline & & 371 & 21 & 0.95 & 7.19 & 65.67 & 73.81 & 162.81 & 81.6 & -0.33 \\
\hline & $92-183$ & 364 & 43 & 1.09 & 65.77 & 260.88 & 327.74 & 261.53 & 115.2 & -0.59 \\
\hline & & 349 & 45 & 0.11 & 14.78 & 102.78 & 117.67 & 149.80 & 122.1 & -0.53 \\
\hline & & 390 & 29 & 0.34 & 19.17 & 94.69 & 114.21 & 128.00 & 125.1 & -0.21 \\
\hline & & 370 & 27 & 3.19 & 102.70 & 223.48 & 329.37 & 166.81 & 129.4 & -0.34 \\
\hline & & 341 & 21 & 0.14 & 15.10 & 110.95 & 126.19 & 123.52 & 134.1 & -0.42 \\
\hline & & 385 & 43 & 1.00 & 87.77 & 200.65 & 289.42 & 154.88 & 134.3 & -0.16 \\
\hline & & 328 & 8 & 0.25 & 13.00 & 62.25 & 75.50 & 44.88 & 137.9 & -0.73 \\
\hline & & 342 & 12 & 0.00 & 8.42 & 92.58 & 101.00 & 119.50 & 140.1 & -0.63 \\
\hline & & 343 & 13 & 0.00 & 6.54 & 161.23 & 167.77 & 189.46 & 153.5 & -0.67 \\
\hline & & 365 & 27 & 2.00 & 115.00 & 296.37 & 413.37 & 204.85 & 155.1 & -0.20 \\
\hline & & 348 & 47 & 1.04 & 88.40 & 356.60 & 446.04 & 211.04 & 163.3 & -0.60 \\
\hline & $184-274$ & 391 & 20 & 0.65 & 11.15 & 50.50 & 62.30 & 31.20 & 201.7 & 0.73 \\
\hline & & 347 & 25 & 0.08 & 17.24 & 118.96 & 136.28 & 116.60 & 209.9 & 0.44 \\
\hline & & 344 & 18 & 0.00 & 7.72 & 71.06 & 78.78 & 136.39 & 212.6 & 0.68 \\
\hline & & 366 & 28 & 0.07 & 9.21 & 50.89 & 60.18 & 75.57 & 218.3 & 0.97 \\
\hline & & 369 & 25 & 0.24 & 14.56 & 48.08 & 62.88 & 47.88 & 220.7 & 1.24 \\
\hline & & 386 & 23 & 0.04 & 24.70 & 34.39 & 59.13 & 29.61 & 221.4 & 1.30 \\
\hline & & 389 & 27 & 0.52 & 9.63 & 25.00 & 35.15 & 18.59 & 222.5 & 1.37 \\
\hline & $275-366$ & 346 & 16 & 0.00 & 1.19 & 12.94 & 14.13 & 20.50 & 287.8 & 2.57 \\
\hline & & 345 & 20 & 0.00 & 1.65 & 17.60 & 19.25 & 35.55 & 308.6 & 2.33 \\
\hline & & 387 & 24 & 0.04 & 0.83 & 3.88 & 4.75 & 1.67 & 316.1 & 2.50 \\
\hline & & 388 & 21 & 0.00 & 0.71 & 5.81 & 6.52 & 4.14 & 317.9 & 2.83 \\
\hline & & 368 & 19 & 0.00 & 0.47 & 5.37 & 5.84 & 10.21 & 321.7 & 2.33 \\
\hline & & 392 & 20 & 0.00 & 1.35 & 37.40 & 38.75 & 81.15 & 325.6 & 2.39 \\
\hline \multirow[t]{17}{*}{$3 N$} & $<57$ & 376 & 22 & 0.18 & 5.41 & 42.45 & 48.05 & 69.68 & 50.3 & 1.69 \\
\hline & & 375 & 36 & 0.06 & 2.36 & 16.11 & 18.53 & 28.06 & 51.1 & 1.56 \\
\hline & $57-91$ & 374 & 25 & 0.16 & 4.24 & 34.84 & 39.24 & 63.64 & 60.7 & 0.10 \\
\hline & & 361 & 49 & 0.12 & 4.29 & 9.06 & 13.47 & 29.35 & 62.9 & 1.77 \\
\hline & & 373 & 50 & 0.12 & 6.52 & 28.44 & 35.08 & 53.48 & 65.2 & 0.33 \\
\hline & & 360 & 46 & 0.43 & 9.59 & 71.52 & 81.54 & 69.28 & 66.8 & 1.67 \\
\hline & & 362 & 56 & 0.04 & 4.36 & 22.66 & 27.05 & 52.73 & 70.3 & 0.61 \\
\hline & & 383 & 23 & 0.35 & 4.91 & 27.39 & 32.65 & 50.26 & 76.5 & -0.58 \\
\hline & $92-183$ & 359 & 19 & 0.58 & 32.42 & 112.63 & 145.63 & 75.95 & 117.8 & 3.87 \\
\hline & & 382 & 28 & 0.04 & 4.29 & 58.14 & 62.46 & 53.82 & 122.0 & -0.55 \\
\hline & & 377 & 22 & 0.86 & 57.18 & 114.91 & 172.95 & 77.27 & 143.1 & -0.19 \\
\hline & $184-274$ & 358 & 14 & 0.00 & 1.57 & 5.36 & 6.93 & 6.71 & 221.6 & 3.66 \\
\hline & & 378 & 20 & 0.00 & 3.20 & 13.65 & 16.85 & 25.70 & 230.2 & 1.08 \\
\hline & & 381 & 30 & 0.13 & 4.03 & 20.63 & 24.80 & 46.60 & 230.5 & 0.93 \\
\hline & $275-366$ & 379 & 16 & 0.00 & 0.44 & 2.25 & 2.69 & 4.19 & 307.5 & 2.37 \\
\hline & & 380 & 16 & 0.00 & 0.44 & 3.75 & 4.19 & 8.56 & 309.5 & 1.97 \\
\hline & & 357 & 10 & 0.00 & 0.40 & 2.50 & 2.90 & 3.70 & 314.8 & 3.78 \\
\hline \multirow[t]{18}{*}{30} & $57-91$ & 352 & 51 & 0.06 & 4.06 & 12.18 & 16.29 & 34.67 & 69.9 & 1.67 \\
\hline & & 351 & 46 & 0.02 & 5.89 & 45.91 & 51.83 & 75.22 & 74.6 & 0.76 \\
\hline & & 353 & 25 & 0.16 & 16.64 & 72.44 & 89.24 & 64.80 & 75.2 & 2.14 \\
\hline & & 330 & 29 & 0.52 & 13.10 & 47.14 & 60.76 & 73.93 & 79.3 & 0.07 \\
\hline & & 338 & 31 & 0.61 & 9.00 & 24.94 & 34.55 & 34.58 & 80.7 & 1.16 \\
\hline & & 340 & 26 & 0.27 & 12.19 & 82.31 & 94.77 & 75.62 & 83.3 & 0.14 \\
\hline & & 331 & 13 & 0.23 & 7.77 & 40.54 & 48.54 & 35.85 & 87.5 & 0.14 \\
\hline & $92-183$ & 332 & 17 & 0.65 & 10.88 & 30.12 & 41.65 & 20.65 & 104.4 & 3.46 \\
\hline & & 337 & 19 & 0.42 & 12.79 & 28.05 & 41.26 & 13.47 & 106.7 & 4.39 \\
\hline & & 339 & 10 & 1.00 & 175.60 & 346.60 & 523.20 & 175.80 & 107.2 & -0.27 \\
\hline & & 354 & 15 & 0.93 & 13.67 & 71.60 & 86.20 & 75.13 & 107.7 & 4.75 \\
\hline & & 329 & 19 & 0.26 & 31.42 & 126.11 & 157.79 & 80.84 & 114.5 & 0.34 \\
\hline & $184-274$ & 333 & 13 & 0.00 & 0.31 & 3.23 & 3.54 & 654.00 & 220.8 & 6.39 \\
\hline & & 336 & 18 & 0.06 & 0.22 & 4.89 & 5.17 & 14.72 & 225.6 & 6.44 \\
\hline & & 355 & 12 & 0.08 & 2.25 & 6.67 & 9.00 & 11.75 & 244.5 & 6.23 \\
\hline & $275-366$ & 334 & 13 & 0.08 & 0.08 & 0.38 & 0.54 & 0.31 & 311.1 & 5.63 \\
\hline & & 335 & 13 & 0.00 & 0.62 & 2.15 & 2.77 & 8.08 & 311.6 & 6.15 \\
\hline & & 356 & 7 & 0.14 & 0.71 & 2.29 & 3.14 & 10.71 & 311.9 & 5.50 \\
\hline
\end{tabular}

